\title{
Tips from BTS
}

\section{Geon Ho Bahn}

Editor-in-Chief, Korean Academy of Child and Adolescent Psychiatry

\section{방탄소년단에게서 배울 점}

\section{반 건 호}

대한소아청소년정신의학회 편집위원장

이번 10월호를 발행하면 2016 2017 회기의 마지막 호가 됩 니다. 함께 고생한 홍민하 간행간사와 위원들께 고마움을 전 합니다. 어쩌면 이제 위원에서 해방될까 봐 섭섭해하고 계신 지도 모르겠습니다만, 학회지의 장기적 발전 계획을 위해 이 사회에서 간행이사 임기를 연장해 주셨으므로 좀 더 함께 고 생해 주시기를 진심으로 원합니다.

이번 호의 종설은 우리 학회 산하 대한자폐스펙트럼연구회 를 맡고 있는 신석호 회장의 '사회적 의사소통장애의 임상적 이해'입니다. 원저로는 송파 아이존의 노경란이 2014년 노경란 과 서동수가 개발한 아동청소년 기능평가척도의 현장적응 가 능성을 평가하였습니다. 이주영 등은 실제 우리나라 자폐 관 련 치료기관에서 실시하고 있는 조기 개입 현황을 조사 분석 한 매우 유용한 자료를 제시합니다. 최미지 등의 '한국판 문제 행동 평가도구 표준화 연구'에서는 우리나라 현실에 맞는 자 폐스펙트럼장애 평가도구의 실용화를 위한 자료를 보고합니 다. 양영희 등은 '공격적 문제행동을 보이는 자폐스펙트럼장 애 아동청소년의 임상적 특징'을 분석하고 그에 대한 치료 근 거를 찾아보고자 하였습니다. 서화연 등의 '정신질환을 가진 부모의 자녀들의 정신건강 상태 조사 연구'에서는 이들 자녀 들을 위한 조기 개입 필요성을 시사하였습니다. 박기정 등은 methylphenidate와 atomoxetine이 ADHD 아동의 운동협응 능력에 미치는 효과에 대한 흥미로운 결과를 제시합니다. 하 수희 등은 소아정신과와 신경과와의 협업을 통해 뇌전증 아 동의 자아개념에 영향을 미치는 요인을 검토하였습니다. 김인 태 등은 2013년 시행 이후 초·중·고등학교에서 연례 행사로
정착된 학생정서·행동특성검사에 대한 부모와 교사의 평정 결 과를 제시합니다. 간행위원들과 투고 원고들을 심사하고 읽고 논의하는 과정에서 저자들의 진료와 연구 열정에 감탄하지 않 을 수 없었고, 흥미로운 사실은 자폐스펙트럼장애 관련 연구가 꽤 늘고 있다는 사실입니다.

작년 해외학회 환영만찬에서 소아정신과 의사인 엄마를 따 라온 독일의 십대 소녀가 내가 서울에서 왔다는 것을 알고서 는 “I envy you!"라고 해서 무슨 말이냐고 했더니 "Bities live in your town!"이라고 했습니다. 가뜩이나 독일식 영어는 알아듣기 어려운데 누구랑 같이 사는 게 행복하다는 것인지 당황했습니다. 그때 ‘비티에스’란 BTS(방탄소년단, 防彈少年 團)라는 우리나라 7인조 남성 아이돌 그룹이라는 것과 전 세 계에 팬들이 매우 많다는 것을 알고 놀랐습니다. 검색해 봤 던 BTS 노래 중 하나가 'Ma city'로 가사에 한글과 영어가 섞 여 있습니다. 가사 일부를 소개합니다. "Ma city로와, come to ma city, (중략), 이게 나의 city, welcome to my city." 이들이 지난 봄 '2017 Billboard Music Awards'에서 Justin Bieber, Selena Gomez, Ariana Grande 같은 쟁쟁한 경쟁자를 제치 고 'Top Social Artist' 상을 받게 된 걸 알고 또 놀랐습니다. 한글과 영어가 섞인 가사로 노래를 부르는데도 전 세계 젊은 이들이 BTS를 추종하는 이유는 무엇인지? BTS의 쾌거는 우리나라뿐 아니라 전 세계에 퍼져 있는 팬들의 열광적 지지 덕분일 것입니다. 우리 학회지의 미래 역시 논문 저자들의 실 력과 독자들의 관심이 결정할 것입니다. 간행위원회 멤버들 과 함께 BTS 그룹을 만나 한 수 배워야 할 것 같습니다. 